\title{
Pengaruh Latar Belakang Keluarga, Kepribadian, dan Efikasi Diri Terhadap Intensi Berwirausaha Mahasiswa
}

\author{
Christine Natalita dan Franky Slamet \\ Program Studi S1 Manajemen Fakultas Ekonomi, Universitas Tarumanagara \\ Email: christine.115150015@stu.untar.ac.id
}

\begin{abstract}
The purpose of this research is to examine whether: 1) family background can affect entrepreneurial intention; 2) personality can affect entrepreneurial intention; 3) selfefficacy can affect entrepreneurial intention. Sample was selected using nonprobability sampling technique with convenience sampling method amounted to 100 respondents of university students in Indonesia. Data were measured by Likert scale and analyzed with processing techniques using SmartPLS 3.0 program. The result of this study shows that, 1) family background support positively had affect on entrepreneurial intention; 2) personality support positively had affect on entrepreneurial intention; 3) self-efficacy support positively had affect on entrepreneurial intention. Several recommendations for research are presented based on conclusions and suggestions on the results of this study.
\end{abstract}

Keywords: Family Background, Personality Traits, Self-Efficacy, and Entrepreneurial Intention.

Abstrak: Tujuan dari penelitian ini adalah untuk menguji apakah: 1) latar belakang keluarga dapat mempengaruhi intensi berwirausaha, 2) kepribadian dapat mempengaruhi intensi berwirausaha, 3) efikasi diri dapat mempengaruhi intensi berwirausaha. Sampel dipilih menggunakan Teknik nonprobability sampling dengan jumlah 100 responden mahasiswa di Indonesia. Data diukur dengan skala Likert dan dianalisi dengan Teknik proses yang menggunakan program SmartPLS 3.0. Secara keseluruhan, hasil penelitian ini meunjukkan bahwa, 1) latar belakang keluarga berpengaruh positif terhadap intensi berwirausaha, 2) kepribadian berpengaruh positif terhadap intensi berwirausaha, 3) efikasi diri berpengaruh positif terhadap intensi berwirausaha. Beberapa rekomendasi untuk penelitian disajikan berdasarkan kesimpulan dan saran mengenai hasil penelitian ini.

Kata kunci: Latar Belakang Keluarga, Kepribadian, Efikasi Diri, dan Intensi Berwirausaha.

\section{LATAR BELAKANG}

Kewirausahaan telah menjadi salah satu topik yang paling banyak diteliti dalam literatur penelitian, karena kewirausahaan merupakan elemen penting bagi pembangunan ekonomi dan dapat memberikan motivasi bagi seseorang untuk mencari peluang dalam mencapai kesuksesan. Kewirausahaan terkait dengan orang-orang yang melakukan kegiatan untuk membangun atau menjalankan suatu pekerjaan melalui strategi perusahaan (CEC, 2003). Kewirausahaan dapat ditingkatkan oleh perusahaan dalam meningkatkan 
pertumbuhan lapangan kerja. Di sisi lain, kewirausahaan juga dapat diajarkan melalui pendidikan kewirausahaan karena menjadi wirausaha merupakan salah satu solusi masalah pengangguran di Indonesia. Lulusan perguruan tinggi di Indonesia mempunyai kecenderungan lebih memilih untuk menjadi pencari pekerjaan dibanding menciptakan pekerjaan karena terbatasnya jumlah lowongan kerja sehingga menyebabkan terjadinya pengangguran (Jung dkk., 2013).

Faktor pendukung yang signifikan terhadap intensi wirausaha di kalangan mahasiswa/i adalah pengaruh latar belakang keluarga, kepribadian, dan efikasi diri (Bullough dkk., 2014). Latar belakang keluarga memainkan peran penting dalam mempengaruhi niat anak sehingga anak memiliki preferensi yang kuat untuk berwirausaha (Krueger dkk., 2000). Selain itu faktor yang dipengaruhi berikutnya adalah kepribadian. Kepribadian telah dipelajari secara luas untuk menilai dampak karakteristik individu terhadap intensi wirausaha. Beberapa peneliti menemukan bahwa kepribadian adalah indikator kuat dari intensi wirausaha (Karabulut, 2016). Faktor lainnya ialah efikasi diri yang telah banyak digunakan di dalam bidang studi kewirausahaan. Efikasi diri dapat mempengaruhi niat seseorang dalam berwirausaha. Oleh karena itu, untuk dapat membangun suatu usaha yang baru harus memerlukan kepercayaan diri yang cukup besar agar usaha yang ingin dibentuk dapat berjalan dengan baik (Zhao dkk., 2005).

Berdasarkan latar belakang yang telah diuraikan dan untuk melengkapi berbagai penelitian, maka dilakukan penelitian dengan subjek penelitian yaitu mahasiswa/i aktif S1 (Sarjana) di Indonesia dan menjadikan latar belakang keluarga, kepribadian, dan efikasi diri sebagai prediktor dari intensi berwirausaha. Penelitian ini dilakukan untuk menelaah apakah variabel yang digunakan memiliki dampak terhadap subjek yang akan diteliti.

\section{KAJIAN TEORI}

Teori yang menjadi dasar dari penelitian ini adalah Theory of Planned Behavior. Theory of Planned Behavior (TPB) merupakan perluasan dari Theory of Reasoned Action (TRA). Theory of Planned Behavior (TPB) merupakan teori paling umum yang digunakan untuk mempelajari intensi dan menjelaskan sikap seseorang dalam berperilaku (Ajzen, 1991). Ajzen (2005) mengemukakan bahwa faktor inti dari TPB adalah intensi yang diasumsikan sebagai faktor motivasi yang dapat mempengaruhi perilaku individu. Semakin kuat intensi untuk terlibat dalam sebuah perilaku, maka semakin kuat pula perilaku tersebut dilakukan. Ajzen (2005) juga menambahkan persepsi terhadap pengendalian yang dapat dilakukan (perceived behavioral control) ke dalam TPB. Persepsi ini ditambahkan untuk dapat memahami keterbatasan yang dimiliki individu dalam melakukan perilaku dengan dilakukan atau tidak dilakukannya suatu tindakan.

Covin \& Miller (2014) menyatakan, "Family background, particularly parents accupation, affects the lives of the children, as their parents values and norms can directly or indirectly determine children's attitudes and behaviors." Artinya, latar belakang keluarga, khususnya pekerjaan orang tua dapat mempengaruhi kehidupan anak, karena nilai dan norma orang tua dapat menentukan sikap dan perilaku anak baik secara langsung maupun tidak langsung. Penelitian yang dilakukan oleh Carr \& Sequeira (2007) menyatakan bahwa latar belakang keluarga memiliki dampak positif pada intensi berwirausaha.

Murphy (2005) menyatakan bahwa "kepribadian bersifat dinamis, dan dinamika dimungkinkan oleh adanya fungsi energi dalam kepribadian." Kepribadian telah dipelajari 
secara luas untuk menilai berbagai macam karakteristik individu terhadap intensi berwirausaha. Kim \& Slocum (2008) mengemukakan bahwa kepribadian yang memiliki kemampuan dan keterampilan adalah prediktor penting yang sangat berpengaruh dalam keberhasilan seseorang, karena kepribadian dapat mempengaruhi intensi berwirausaha. Penelitian yang telah dilakukan oleh Karabulut (2016) telah mempertimbangkan bahwa kepribadian memiliki hubungan yang signifikan dengan intensi berwirausaha.

Menurut Bandura (1997) menyatakan, "Self-efficacy is the belief that a person has sufficient ability and capability to excel in what he or she decides or wants to achieve." Artinya, efikasi diri adalah kepercayaan diri seseorang memiliki kemampuan yang cukup untuk mencapai sesuatu yang diinginkan. Efikasi diri dalam diri seseorang menggambarkan pribadi seseorang dalam menentukan intensi berwirausaha sebagai bentuk tahap awal seseorang untuk memulai karirnya (Betz \& Hacket, 2008). Peneliti sebelumnya telah menemukan bahwa efikasi diri merupakan prediktor penting untuk menentukan intensi berwirausaha dan efikasi diri memiliki hubungan yang signifikan dengan intensi berwirausaha (Elali \& Al-Yacub, 2016).

Berdasarkan kajian teori yang ada, model kerangka pemikiran intensi berwirausaha pada mahasiswa disajikan secara visual pada Gambar 1 di bawah ini:

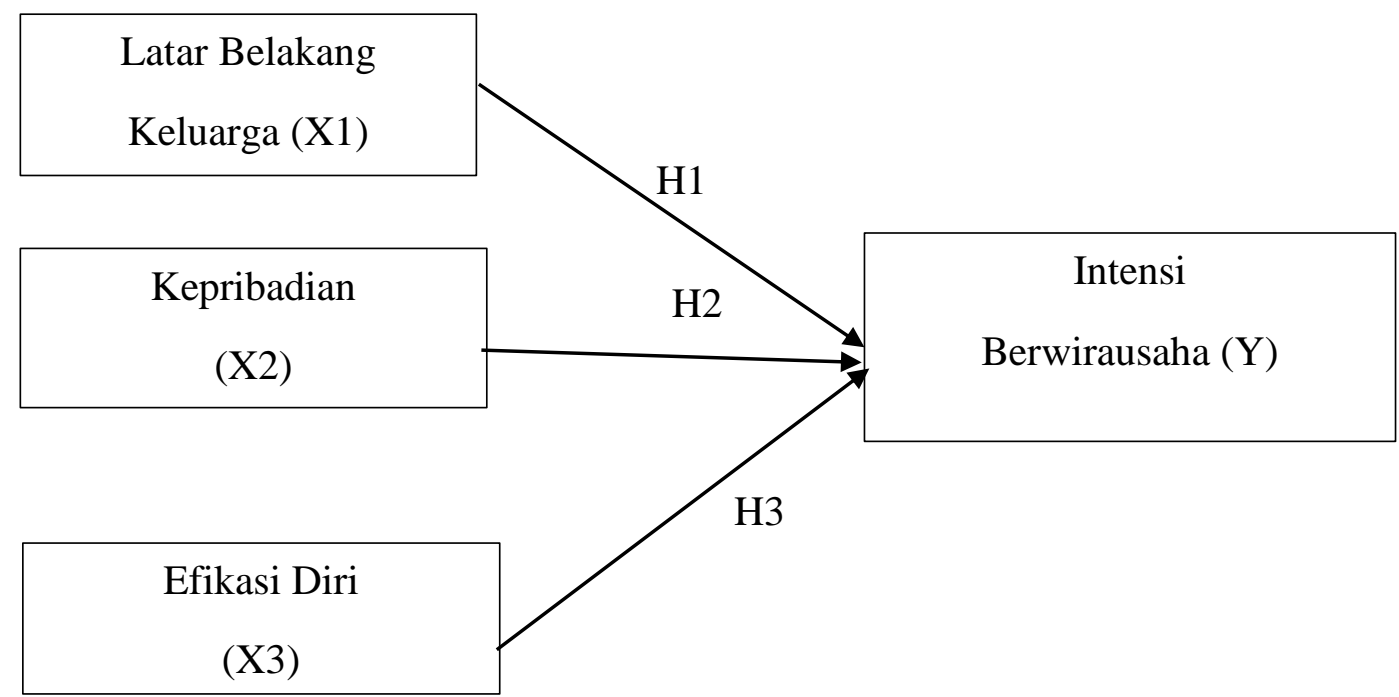

Dari model kerangka pemikiran di atas, hipotesis yang dihasilkan adalah sebagai berikut:

H1: Latar belakang keluarga memiliki pengaruh yang positif terhadap intensi berwirausaha.

$\mathrm{H}$ 2: Kepribadian memiliki pengaruh yang positif terhadap intensi berwirausaha.

H3: Efikasi diri memiliki pengaruh yang positif terhadap intensi berwirausaha.

\section{METODOLOGI}

Penelitian ini merupakan penelitian kuantitatif dengan menggunakan desain penelitian deskriptif karena memuat informasi penelitian sebelumnya dengan variabel yang sama dan hipotesis dalam penelitian ini sudah dapat dirumuskan. Populasi yang dijadikan sebagai subjek penelitian ini adalah mahasiswa/i aktif S1 (Sarjan) di Indonesia. Metode 
pengambilan sampel yang digunakan dalam penelitian ini adalah non-probability sampling. Non-probability sampling adalah teknik pengambilan sampel yang tidak menggunakan prosedur seleksi dan lebih dapat diandalkan karena menawarkan petunjuk yang berguna terkait dengan populasi (Cavan dkk., 2001).

Pada penelitian ini, teknik pemilihan sampel yang digunakan adalah judgemental sampling. Judgemental sampling merupakan bentuk dari convenience sampling yang di dalam sampel tersebut terdapat elemen populasi yang secara sengaja dipilih berdasarkan penilaian peneliti (Malhotra, 2004, h. 322). Dengan demikian, sampel penelitian ini adalah mahasiswa/i S1 (Sarjana) di Indonesia yang telah menempuh mata kuliah kewirausahaan. Sekaran \& Bougie (2013:269) juga mengemukakan bahwa ukuran sampel yang lebih besar dari 30 dan kurang dari 500 adalah jumlah yang tepat untuk kebanyakan penelitian. Penelitian ini mengambil sampel sebanyak 100 responden dengan kriteria yaitu merupakan mahasiswa/i aktif S1 (Sarjana) di Indonesia yang telah menempuh mata kuliah kewirausahaan.

Berdasarkan data yang didapat dari 100 (100\%) responden, sebanyak 61 (61\%) responden berjenis kelamin wanita, dan 31 (31\%) responden berjenis kelamin pria. Kemudian, mayoritas responden berdomisili di Jakarta, yaitu sebesar $20 \%$ dan paling sedikit yaitu responden berdomisili di Pontianak sebesar $2(2 \%)$ responden. Selain itu, sebanyak 24\% responden berasal dari kota lain di Indonesia seperti Blitar, Surabaya, Semarang, dan Mataram. Penelitian ini menerapkan penggunaan skala Likert sebagai pemberian skor dari setiap indikator dan penyebaran kuesioner dilakukan secara online melalui internet dengan menggunakan google form. Menurut Burns dan Bush (2014:208) skala Likert menjelaskan intensitas seberapa setuju atau tidaknya responden terhadap butirbutir pernyataan yang dapat dilihat dari lima poin skala yang ada (sangat tidak setuju sangat setuju).

Hasil Uji Statistik. Hair dkk. (2011) maupun Henseler dkk. (2009) menyatakan bahwa uji validitas dapat dilakukan dengan cara mengevaluasi convergent validity dan discriminant validity dalam model penelitian tersebut. Convergent validity diuji dengan menggunakan loading factor dari setiap indikator dan average extracted variance (AVE) dari setiap variabel.

Tabel 1. Hasil Nilai Average Variance Extracted (AVE)

\begin{tabular}{|c|c|}
\hline Variabel & $\begin{array}{c}\text { Average Extracted Variance } \\
\text { (AVE) }\end{array}$ \\
\hline Latar Belakang Keluarga & 0,667 \\
\hline Kepribadian & 0,642 \\
\hline Efikasi Diri & 0,621 \\
\hline Intensi Berwirausaha & 0,597 \\
\hline$\overline{A V E}$ & 0,632 \\
\hline
\end{tabular}

Sumber: Pengolahan Data SmartPLS 3.0

Hasil dari AVE menunjukkan nilai sebesar 0,667 untuk variabel latar belakang keluarga, 0,642 untuk variabel kepribadian, 0,621 untuk variabel efikasi diri, dan 0,597 untuk variabel intensi berwirausaha. Hasil ini menunjukkan bahwa setiap variabel di atas telah memenuhi kriteria dengan nilai AVE yang lebih besar dari 0,5 (Hair dkk., 2011). Selanjutnya, suatu indikator dinyatakan valid jika mempunyai loading factor di atas 0.7 terhadap konstruk yang dituju, apabila dalam sebuah model penelitian terdapat indikator 
yang memiliki nilai loading factor di bawah 0,7, maka indikator tersebut harus dihilangkan (Henseler dkk., 2009). Terdapat beberapa indikator yang tidak memenuhi kriteria loading factor sehingga indikator-indikator tersebut harus dihapuskan.

Tabel 2. Hasil Nilai Loading Factor

\begin{tabular}{|c|c|c|}
\hline \multicolumn{2}{|r|}{ Indikator } & Loading \\
\hline LB1 & $\begin{array}{l}\text { Pendidikan kewirausahaan di universitas mendorong saya untuk } \\
\text { mengembangkan ide-ide kreatif untuk menjadi seorang wirausaha. }\end{array}$ & 0,801 \\
\hline LB2 & $\begin{array}{l}\text { Universitas saya memberikan pengetahuan penting tentang } \\
\text { kewirausahaan. }\end{array}$ & 0,726 \\
\hline LB3 & $\begin{array}{l}\text { Universitas saya mengembangkan keterampilan dan kemampuan } \\
\text { berwirausaha saya. }\end{array}$ & 0,803 \\
\hline KP3 & $\begin{array}{l}\text { Saya melihat diri saya sebagai seseorang yang menghasilkan banyak } \\
\text { antusiasme. }\end{array}$ & 0,733 \\
\hline KP14 & Saya melihat diri saya sebagai seseorang yang perhatian. & 0,726 \\
\hline KP23 & $\begin{array}{l}\text { Saya melihat diri saya sebagai seseorang yang bertahan sampai tugas } \\
\text { selesai. }\end{array}$ & 0,701 \\
\hline KP24 & $\begin{array}{l}\text { Saya melihat diri saya sebagai seseorang yang mengerjakan sesuatu } \\
\text { secara efisien. }\end{array}$ & 0,731 \\
\hline KP25 & Saya melihat diri saya sebagai seseorang yang membuat rencana. & 0,728 \\
\hline KP37 & Saya melihat diri saya sebagai seseorang yang memiliki ide-ide baru. & 0,769 \\
\hline KP39 & Saya melihat diri saya sebagai seseorang yang cerdik. & 0,786 \\
\hline KP41 & Saya melihat diri saya sebagai seseorang yang mempunya imajinasi. & 0,796 \\
\hline ED1 & $\begin{array}{l}\text { Saya selalu dapat mengelola untuk menyelesaikan masalah yang sulit } \\
\text { jika saya sudah cukup mencoba. }\end{array}$ & 0,737 \\
\hline ED3 & Mudah bagi saya untuk tetap pada tujuan saya. & 0,843 \\
\hline ED4 & Mudah bagi saya untuk mencapai tujuan saya. & 0,791 \\
\hline ED5 & $\begin{array}{l}\text { Saya yakin bahwa saya dapat menangani secara efisien pada peristiwa } \\
\text { yang tidak terduga. }\end{array}$ & 0,816 \\
\hline ED6 & $\begin{array}{l}\text { Terima kasih kepada akal saya, saya jadi tahu bagaimana menangani } \\
\text { situasi yang tidak terduga. }\end{array}$ & 0,777 \\
\hline ED7 & $\begin{array}{l}\text { Saya dapat memecahkan sebagian besar masalah saya, jika saya } \\
\text { menginvestasikan upaya yang diperlukan. }\end{array}$ & 0,764 \\
\hline ED8 & $\begin{array}{l}\text { Saya bisa tetap tenang ketika saya menghadapi kesulitan karena saya } \\
\text { bisa mengandalkan kemampuan saya. }\end{array}$ & 0,765 \\
\hline
\end{tabular}




\begin{tabular}{|c|l|c|}
\hline ED9 & $\begin{array}{l}\text { Ketika saya dihadapkan dengan masalah, saya biasanya dapat } \\
\text { menemukan solusi. }\end{array}$ & 0,886 \\
\hline ED10 & Jika saya sedang dalam masalah, saya biasanya memikirkan solusinya. & 0,817 \\
\hline ED11 & Saya dapat mengandalkan apapun dengan cara saya sendiri. & 0,786 \\
\hline IB1 & Saya berniat untuk mendirikan perusahaan di masa depan. & 0,781 \\
\hline IB2 & Saya akan memilih karir sebagai seorang wirausaha. & 0,744 \\
\hline IB3 & $\begin{array}{l}\text { Saya lebih memilih untuk menjadi seorang wirausaha daripada menjadi } \\
\text { seorang karyawan yang bekerja di perusahaan atau di organisasi. }\end{array}$ & 0,812 \\
\hline IB4 & $\begin{array}{l}\text { Saya memiliki ide yang menarik untuk memulai bisnis sendiri pada } \\
\text { suatu saat. }\end{array}$ & 0,836 \\
\hline IB5 & Saya ingin bebas mengekspresikan diri saya di bisnis saya sendiri. & 0,829 \\
\hline
\end{tabular}

Sumber: Pengolahan Data SmartPLS 3.0

Berdasarkan hasil dari Tabel 2, telah menunjukkan bahwa seluruh indikator memiliki nilai loading factor di atas 0,6 di mana telah memenuhi syarat convergent validity (Hair dkk., 2011), sehingga dapat disimpulkan bahwa semua variabel yang ada dalam penelitian ini telah memenuhi kriteria convergent validity. Dalam pengujian discriminant validity, nilai Fornell-Larcker yang dimiliki oleh masing-masing variabel pada penelitian ini memenuhi kriteria karena nilai akar kuadrat AVE lebih besar daripada korelasi antar konstruk serta nilai cross-loadings masing-masing indikator setiap variabel lebih besar dari nilai cross-loadings variabel lainnya. Berdasarkan hasil analisis convergent validity maupun discriminant validity, maka dapat disimpulkan bahwa variabel dan indikator yang digunakan dalam penelitian ini valid.

Tabel 3. Hasil Pengujian Reliabilitas

\begin{tabular}{|c|c|c|}
\hline Variabel & Cronbach Alpha's & $\begin{array}{l}\text { Composite } \\
\text { Reliability }\end{array}$ \\
\hline Efikasi Diri & 0,944 & 0,952 \\
\hline Intensi Berwirausaha & 0,861 & 0,871 \\
\hline Kepribadian & 0,913 & 0,914 \\
\hline Latar Belakang Keluarga & 0,664 & 0,661 \\
\hline
\end{tabular}

Sumber: Pengolahan Data SmartPLS 3.0

Berdasarkan Tabel 3.9, dapat diketahui bahwa nilai cronbach's alpha pada penelitian ini memiliki nilai di atas 0,6 , yaitu efikasi diri memiliki nilai sebesar 0,938 , intensi berwirausaha memiliki nilai sebesar 0,861, kepribadian memiliki nilai sebesar 0,912, dan latar belakang keluarga memiliki nilai sebesar 0,676. Nilai composite reliability juga 
berada pada nilai di atas 0,7 , yaitu efikasi diri dengan nilai sebesar 0,948 , intensi berwirausaha dengan nilai sebesar 0,899, kepribadian dengan nilai sebesar 0,928 , dan latar belakang keluarga dengan nilai sebesar 0,821. Berdasarkan nilai tersebut, maka dapat disimpulkan bahwa data pada penelitian reliabel ini telah memenuhi kriteria.

Setelah pengujian outer model (validitas dan reliabilitas), pengolahan data variabelvariabel penelitian dilanjutkan pada tahapan pengujian inner model (model struktural) untuk dapat mengetahui kontribusi dari variabel-variabel independen (X) terhadap variabel-variabel dependen (Y). Kriteria pengujian model struktural yang harus dipenuhi pada penelitian ini yaitu nilai koefisien determinasi $\left(\mathrm{R}^{2}\right)$, predictive relevance $\left(\mathrm{Q}^{2}\right)$, dan path coefficients.

Hasil nilai koefisen determinasi $\left(\mathrm{R}^{2}\right)$ pada penelitian ini adalah sebesar 0,592 , berarti $59,2 \%$ dari variabel dependen yaitu intensi berwirausaha dapat dijelaskan oleh variabel independen yang terdapat pada penelitian ini dan sisanya yaitu sebesar 40,8\% dapat dijelaskan oleh variabel-variabel yang tidak termasuk dalam penelitian ini. Berdasarkan kriteria nilai R-Square yang dikemukakan oleh Cohen (1988) nilai R-Square berada di antara 0,25 dan 0,49 yang artinya memiliki pengaruh lemah. Uji selanjutnya adalah predictive relevance $\left(\mathrm{Q}^{2}\right)$ dengan hasil yang didapatkan sebesar $0,334\left(\mathrm{Q}^{2}>0\right)$. Artinya, variabel penjelas intensi berwirausaha yang berupa latar belakang keluarga, kepribadian, dan efikasi diri dapat menunjukkan relevansi prediksi yang memadai atau memprediksi model dengan baik. Pengujian berikutnya adalah Goodness of Fit (GoF), dengan hasil sebesar 0,612, Wetzels dkk. (2009) menyebutkan bahwa model yang digunakan pada penelitian ini memiliki tingkat kecocokan yang besar.

Tabel 3. Hasil Bootstrapping

\begin{tabular}{|c|c|c|c|}
\hline & Path Coefficient & t-statistics & p-value \\
\hline $\begin{array}{c}\text { Latar Belakang Keluarga } \\
\rightarrow \text { Intensi Berwirausaha }\end{array}$ & 0,269 & 3,179 & 0,003 \\
\hline $\begin{array}{c}\text { Kepribadian } \rightarrow \text { Intensi } \\
\text { Berwirausaha }\end{array}$ & 0,355 & 3,912 & 0,000 \\
\hline $\begin{array}{c}\text { Efikasi Diri } \rightarrow \text { Intensi } \\
\text { Berwirausaha }\end{array}$ & 0,250 & 2,400 & 0,013 \\
\hline
\end{tabular}

Sumber: Pengolahan Data SmartPLS 3.0

Berdasarkan tabel di atas, hasil pengujian bootstrapping (hipotesis) dari seluruh variabel memiliki nilai t-statistics $>1,96$ dan nilai p-values $<0,05$, sehingga dapat dikatakan bahwa hipotesis tidak ditolak dan memiliki arah hubungan yang positif.

Hasil pengujian hipotesis pertama yang didapatkan untuk variabel latar belakang keluarga telah menunjukkan nilai t-statistics sebesar 3,179 dengan p-value sebesar 0,003. Nilai tersebut lebih besar dari cut-off value sebesar 1,96 dan p-value yang lebih kecil dari 0,05 sehingga $\mathrm{H} 1$ tidak ditolak. Oleh karena itu, dapat disimpulkan bahwa latar belakang keluarga berpengaruh secara positif terhadap intensi berwirausaha.

Hasil pengujian hipotesis kedua yang didapatkan untuk variabel kepribadian menunjukkan nilai t-statistics sebesar 3,912 dengan p-value sebesar 0,000. Nilai tersebut lebih besar dari cut-off value sebesar 1,96 dan p-value yang lebih kecil dari 0,05 sehingga $\mathrm{H} 2$ tidak ditolak. Oleh karena itu, dapat disimpulkan bahwa kepribadian berpengaruh secara positif terhadap intensi berwirausaha. 
Hasil pengujian hipotesis ketiga yang didapatkan untuk variabel efikasi diri menunjukkan nilai t-statistics sebesar 2,400 dengan p-value sebesar 0,013. Nilai tersebut lebih besar dari cut-off value sebesar 1,96 dan p-value yang lebih kecil dari 0,05 sehingga H3 tidak ditolak. Oleh karena itu, dapat disimpulkan bahwa efikasi diri berpengaruh secara positif terhadap intensi berwirausaha.

Gambar 2. Hasil Pengujian Bootstrapping

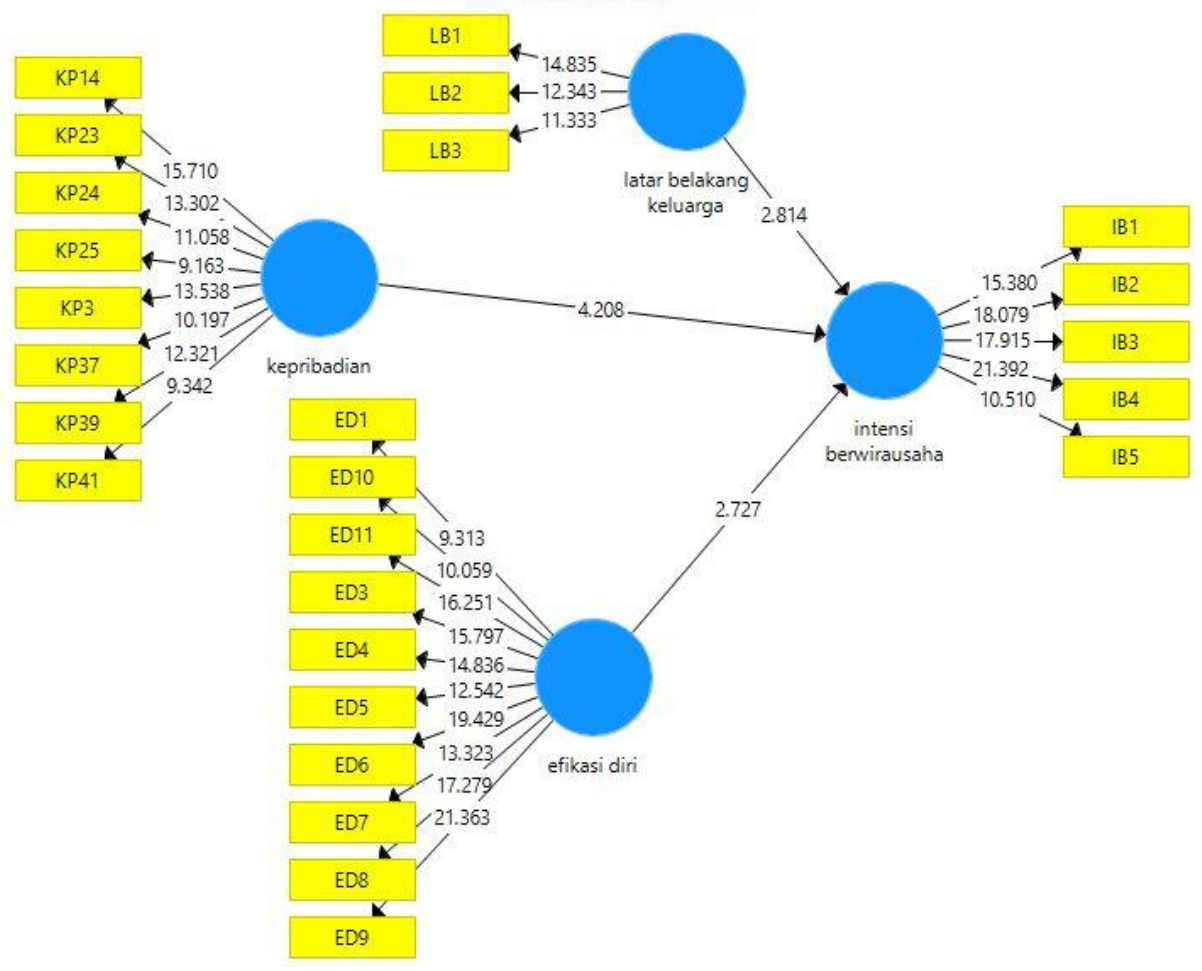

\section{DISKUSI}

Dari analisis data yang telah dilakukan, pengujian pada penelitian ini telah menghasilkan hasil yang sesuai dengan hipotesis. Hasil dari pengujian hipotesis menunjukkan terdapat pengaruh yang positif dari latar belakang keluarga terhadap intensi berwirausaha pada mahasiswa. Kemudian, hasil dari pengujian hipotesis dari kepribadian juga menunjukkan pengaruh yang positif terhadap intensi berwirausaha pada mahasiswa. Pada efikasi diri, hasil pengujian hipotesis menunjukkan bahwa terdapat pengaruh yang positif dari efikasi diri terhadap intensi berwirausaha pada mahasiswa.

\section{KESIMPULAN}

Berdasarkan hasil dari keseluruhan pengujian data penelitian ini, telah menunjukkan bahwa latar belakang keluarga memiliki pengaruh yang positif terhadap intensi berwirausaha pada mahasiswa. Hal ini terjadi karena orang tua telah mendukung anaknya secara penuh untuk memberikan dorongan kepada anak-anaknya untuk menjadi seorang wirausaha. Kemudian, kepribadian juga memiliki pengaruh yang positif terhadap intensi berwirausaha pada mahasiswa sehingga dapat disimpulkan bahwa Orang yang memiliki 
kepribadian terbuka memiliki peran penting dalam pemanfaatan sumber daya dengan mengembangkan jaringan yang ada secara efisien dan efektif dan orang yang memiliki kepribadian terbuka dianggap sebagai orang yang ingin mencari pengalaman baru dalam memulai suatu usaha yang baru (Farrukh dkk., 2016).

Selain latar belakang keluarga dan kepribadian, efikasi diri juga memiliki pengaruh yang positif terhadap intensi berwirausaha pada mahasiswa. Seseorang yang memiliki rasa percaya diri yang tinggi akan lebih mudah untuk membuat keputusan dalam membangun usaha mereka sendiri karena mereka yakin dengan kemampuan mereka untuk beradaptasi dengan lingkungannya (Margahana \& Garaika, 2019).

Dalam sebuah penelitian tentunya terdapat keterbatasan termasuk penelitian ini. Keterbatasan-keterbatasan dalam penelitian ini, yaitu: 1) Dalam penelitian ini menggunakan empat variabel yang terdiri dari tiga variabel independen dan satu variabel dependen. Variabel independen pada penelitian ini yaitu latar belakang keluarga, kepribadian, dan efikasi diri. Dan variabel dependen pada penelitian ini yaitu intensi berwirausaha. Semua variabel yang diteliti pada penelitian ini masih terbilang cukup terbatas untuk memprediksi intensi berwirausaha pada penelitian ini. 2) Sehubungan dengan waktu yang relatif singkat dan cakupan wilayah yang cukup luas, sehingga menyebabkan responden dari penelitian ini juga terbatas dan kurang mempresentasikan mahasiswa di seluruh kota yang ada di Indonesia sebagai objek penelitian karena responden yang didapat hanya berasal dari beberapa kota tertentu.

Berdasarkan hasil dan keterbatasan di atas, maka saran yang dapat diberikan untuk melakukan penelitian selanjutnya adalah diharapkan agar jangkauan pengambilan sampel dapat mewakili setiap wilayah yang telah ditentukan dalam penelitian, sehingga setiap respondennya dapat mewakili subjek penelitian dengan tepat. Selain itu, disarankan agar lebih diperbanyak dan ditambahkan variabel-variabel lain seperti dukungan pendidikan, dukungan relasi, lingkungan pendidikan, kreatifitas yang berpengaruh terhadap intensi berwirausaha.

\section{DAFTAR PUSTAKA}

Ajzen, I. (1991). The theory of planned behavior. Organizational Behavior and Human Decision Processes, 50(2), 179-211.

Bandura, A. (1977), "Self-efficacy: Toward a Unifying Theory of Behavioral Change", Psychological Review, 84 (2), 191.

BarNir, A., Watson, W.E. \& Hutchins, H.M. (2011), "Mediation and Moderated Mediation in The Relationship Among Role Models, Self-Efficacy, Entrepreneurial Career Intention, and Gender", Journal of Applied Social Psychology, 41(2), 270-297

Cavana, Delahaye, R.Y., Brian L., \& Sekaran, U. (2001). Applied Business research: Qualitative and Quantitative Methods. Queensland: John Wiley \& Sons Inc, Milton.

Cohen, Jacob. (1988). Statiscal Power Analysist for the Behavioral Sciences (Ed. 2). Hillsdale: Erlbaum Associates.

Covin, J.G. \& Miller, D. (2014), “International Entrepreneurial Orientation: Conceptual Considerations, Research Themes, Measurement Issues, and Future Research Directions",Entrepreneurship Theory and Practice, 38 (1), 11-44.

Farrukh, M., Khan, A. A., Shahid Khan, M., Ravan Ramzani, S., \& Soladoye, B. S. A. (2017). Entrepreneurial Intentions: The Role of Family Factors, Personality Traits 
and Self-Efficacy. World Journal of Entrepreneurship, Management And Sustainable Development, 13(4), 303-317.

Garaika, \& Margahana, H. (2019). Self Efficacy, Self Personality and Self Confidence on Entrepreneurial Intention: Study on Young Enterprises. Journal of Entrepreneurship Education, 2(1).

Gelaidan, H.M., Abdullateef, A.O. (2017). Entrepreneurial intentions of business students in Malaysia: The role of self-confidence, educational and relation support. Journal of Small Business and Enterprise Development, 24(1), 54-67.

Hair, J. F., Ringle, C. M., \& Sarstedt, M. (2011). PLS-SEM: Indeed a Silver Bullet. The Journal of Marketing Theory and Practice, 19(2), 139-151.

Henderson, R., \& Robertson, M. (2000). Who wants to be an entrepreneur? Young adult attitudes to entrepreneurship as a career". Career Development International, 5(6), 279-287.

Henseler, J., Ringle, C. M., \& Sinkovics, R. R. (2009). The use of partial least square path modeling in International Marketing. Advances in International Marketing, 20, 277319.

Kusmintarti, A., Asdani, A., \& Riwajanti, N.I. (2017). The relationship between creativity, entrepreneurial attitude and entrepreneurial intention (case study on the students of State Polytechnic Malang). Int. J. Trade and Global Markets, 10(1), 28-36.

Sekaran, U., \& Bougie, R. (2013). Research Methods for Business (6th ed.). Italy: Printer Trento Srl.

Wetzels, M., Odekerken-Schroder, G., \& Van Oppen, C. (2009). Using PLS path modeling for assessing hierarchical construct models: Guidelines and empirical illustration. MIS Quarterly, 33(1), 177-195.

Yurtkoru, S. Kuşcu, Z.K., \& Doğanay, A. (2014). Exploring the Antecedents of Entrepreneurial Intention on Turkish University Students. Procedia- Social and Behavioral Sciences, 150, 841-850. 